\title{
Congenital biscuspid aortic valve in pediatric and early adulthood: Is there a relationship between the valvular leaflet fusion pattern and other functional parameters
}

Noha Behairy*, Ahmed Ramadan, Ahmed E Kharabish

From 19th Annual SCMR Scientific Sessions

Los Angeles, CA, USA. 27-30 January 2016

\section{Background}

Bicuspid aortic valve (BAV) represents the most frequent congenital cardiac abnormality resulting in premature valvular degeneration and aortic dilatation.

Our aim was to detect a relationship between the leaflet fusion pattern and other functional parameters including valvular regurge, stenosis and pressure gradient.

\section{Methods}

One hundered patients between 3 months to 26 years were included in the study. They were 78 males and 22 females. BSA for the patients ranged from 0.45-2.27. All patients were subjected to clinical examination, transthoracic echocardiography and CMR on a 1.5T machine. We recorded the leaflet fusion pattern, presence of AS, AR, pressure gradient, EF, LVEDV, aortic diameter at the annulus, sinus, arch and ascending aorta levels. Associated findings were all recorded.

\section{Results}

Sixty patients had right and left coronary cusps (R-L) fusion showing mean pressure gradient of $23.5 \pm 14.8$ of those $48 \%$ patients showed AS while $52 \%$ had AR. Forty patients had right and noncoronary cusps (R-N) fusion with $44.5 \pm 31$ pressure gradient with $\mathrm{P}=0.02$, of those $75 \%$ had AS while $45 \%$ had AR with $20 \%$ showing combined lesions. Ejection fraction was within normal range except in patients with associated myocardial lesions. LVEDV ranged from $49-185 \mathrm{ml}$. Aorta was dilated in 38 cases with no predilection for any leafleted fusion type. Associated co-aorctation of the aorta was detected in

Radiology, Cairo University, Cairo, Egypt creativecommons.org/licenses/by/4.0), which permits unrestricted use, distribution, and reproduction in any medium, provided the original work is properly cited. The Creative Commons Public Domain Dedication waiver (http://creativecommons.org/publicdomain/ zero/1.0/) applies to the data made available in this article, unless otherwise stated. 
doi:10.1186/1532-429X-18-S1-P344

Cite this article as: Behairy et al:: Congenital biscuspid aortic valve in pediatric and early adulthood: Is there a relationship between the

valvular leaflet fusion pattern and other functional parameters. Journal of Cardiovascular Magnetic Resonance 2016 18(Suppl 1):P344.

Submit your next manuscript to BioMed Central and take full advantage of:

- Convenient online submission

- Thorough peer review

- No space constraints or color figure charges

- Immediate publication on acceptance

- Inclusion in PubMed, CAS, Scopus and Google Scholar

- Research which is freely available for redistribution

Submit your manuscript at www.biomedcentral.com/submit

() Biomed Central 